\title{
Manajemen Public Relations dan Reputasi Organisasi Lembaga Amil Zakat Dompet Dhuafa
}

\author{
Ahmad Dimyati \\ Prodi Manajemen Fakultas Ekonomi Universitas Pamulang \\ Email: dimyatiachmad99@gmail.com
}

\begin{abstract}
ABSTRAK
Penelitian ini bertujuan untuk mengetahui (1) metode identifikasi masalah Public Relations pada LAZ Dompet Dhuafa; (2) proses perencanaan dan pemrograman LAZ Dompet Dhuafa; (3) strategi aksi dan komunikasi LAZ Dompet Dhuafa; dan (4) proses evaluasi program LAZ Dompet Dhuafa. Penelitian ini menggunakan metode kualitatif dengan pendekatan studi kasus eksploratif jenis single case holistic. Data primer dalam penelitian ini diperoleh melalui wawancara mendalam, sementara data sekunder bersumber dari studi pustaka dan dokumentasi. Hasil penelitian menunjukkan bahwa LAZ Dompet Dhuafa tidak melakukan riset khusus terkait perencanaan program; riset yang dilakukan hanya melalui fakta-fakta baru di lapangan melalui program-program yang sudah ada sebelumnya. Perencanaan program tematik dan nontematik LAZ Dompet Dhuafa dilakukan melalui rapat kerja tahunan, sementara pesan utama yang ingin disampaikan kepada pihak eksternal disampaikan melalui website resmi dan media sosial. Adapun evalusi program yang dilakukan tidak melibatkan publik eksternal.
\end{abstract}

Kata Kunci: Manajemen Public Relations, zakat, Dompet Dhuafa

\begin{abstract}
This study aims to determine (1) the method of identifying problems of Public Relations at LAZ Dompet Dhuafa; (2) the planning and programming process of LAZ Dompet Dhuafa; (3) the strategy of action and communication of LAZ Dompet Dhuafa; and (4) the evaluation process of the LAZ Dompet Dhuafa program. This study uses a qualitative method with an explorative case study approach and single case holistic. The primary data in this study were obtained through in-depth interviews, while the secondary data were obtained from literature and documentation. The results of the study show that LAZ Dompet Dhuafa does not conduct specific research related to program planning; the research only carried out through new facts in the field through the preexisting programs. The planning of thematic and non-thematic program is carried out through annual work meetings, while the main message to be conveyed to public (external) is delivered through the official website and social media. Meanwhile, the evaluation of the program did not involve the external public.
\end{abstract}

Keywords: Public Relations management, zakat, Dompet Dhuafa

\section{PENDAHULUAN}

Semenjak didirikan dua dekade yang lalu, LAZ Dompet Dhuafa telah meluncurkan berbagai inovasi dalam menyalurkan infak dan zakat. Berkat upaya inovasi yang berbasis pada pelayanan masyarakat tersebut, LAZ Dompet Dhuafa memiliki reputasi yang baik di mata para donaturnya, dan reputasi tersebut dapat menjadi tolok ukur bagi organisasi nirlaba lainnya di Indonesia. Bahkan, dan lebih jauh lagi, LAZ Dompet Dhuafa berkembang bukan

Citation : Dimyati, Ahmad. (2018). “Manajemen Public Relations dan Reputasi Organisasi Lembaga Amil Zakat Dompet Dhuafa". Nyimak Journal of Communication, 2(2): 167-185. 
hanya sebagai lembaga zakat semata, namun juga semakin berkembang menjadi lembaga sosial kemanusiaan (Nurdin, 2013).

Dikutip dari website resmi LAZ Dompet Dhuafa, berbagai program inovasi berbasis pelayanan masyarakat tersebut antara lain Bimbingan Rohani Pasien (BRP), Shelter Pasien, Ibu Tangguh, Pejuang Keluarga, Koprs Dai Dompet Dhuafa, Dai Samudra, Dai Tapal Batas, Musholla Tapal Batas, Bedah Musholla, Kartu Ukhuwah, Benah Fasilitas Layanan Sosial, Ketahanan Keluarga Berbasis Majlis Taklim, Pengelolaan Penderita Psikotik, Bedah Panti dan Bedah Rumah, Layanan Darurat Kemiskinan, Layanan Dakwah Lembaga Pemasyarakatan, Lantas Berdaya, dan Layanan Mustahik (Lamusta).

Sementara itu, dalam upaya membangun reputasi organisasi, berbagai strategi yang dilakukan oleh LAZ Dompet Dhuafa antara lain dengan memanfaatkan media massa (Harian Republika, Majalah Swaracinta, dan lain sebagainya), membuat website sebagai sarana informasi bagi masyarakat luas, menyediakan sarana dan tenaga untuk kebutuhan konsultasi, mengadakan pelatihan atau penyuluhan, membuat materi publikasi (baliho, brosur, banner), dan melakukan komunikasi serta koordinasi secara intens dengan para pegawai atau volunter yang pernah bekerja di LAZ Dompet Dhuafa.

Dalam hal ini, organisasi nirlaba memerlukan pengelolaan yang berbeda dengan organisasi profit dan pemerintahan, karena pencapaian, kinerjanya tidak semata-mata didasarkan atas pertimbangan ekonomi, melainkan sejauh mana masyarakat yang dilayaninya bisa diberdayakan sesuai dengan konteks hidup dan potensi-potensi kemanusiaannya. Artinya, ciri khas pelayanan organisasi nirlaba adalah memiliki sifat sosial dan kemanusiaan, karena manusia merupakan pusat sekaligus agen perubahan dan pembaruan masyarakat. Tujuannya antara lain mengurangi kemiskinan, mewujudkan kesejahteraan, kesetaraan gender, keadilan, bebas dari konflik dan kekerasan.

Dengan demikian, efektivitas dalam proses komunikasi perlu dilakukan melalui proses manajemen terpadu, terarah, dan tepat sasaran. Manajemen harus mampu memaksimalkan pengelolaan sumberdaya komunikasi yang ada untuk meningkatkan kualitas dan efektivitas pertukaran pesan dalam berbagai konteks komunikasi (individual, organisasional, governmental, sosial, atau internasional).

Pengelolaan sumberdaya komunikasi dalam organisasi salah satunya diperankan oleh Public Relations (PR) yang merupakan bagian dalam proses manajemen komunikasi antara organisasi dengan publiknya (Ruslan, 2007). Salah satu aktivitas utama PR adalah menjembatani fungsi manajemen (organisasi) dalam berkomunikasi dengan publiknya, terutama dalam menjaga reputasi perusahaan, menjaga kepercayaan, dan membina hubungan baik dengan stakeholders. 
Dalam proses manajemen, aktivitas PR sendiri mempunyai empat langkah strategis: (1) mendefinisikan masalah atau peluang, yang mana fungsi ini menyediakan dasar untuk semua langkah dalam proses pemecahan masalah dengan menentukan "apa yang sedang terjadi saat ini"; (2) perencanaan dan pemrograman, yaitu langkah yang dilakukan untuk menjawab pertanyaan "berdasarkan apa kita mengetahui sebuah situasi atau keadaan, dan apa yang harus dilakukan, atau apa yang harus diubah, atau apa yang harus dikatakan"; (3) mengambil tindakan dan berkomunikasi, yaitu dalam bentuk pertanyaan "siapa yang harus melakukan dan menyampaikannya, kapan, di mana, dan bagaimana caranya"; (4) mengevaluasi program, yaitu untuk menjawab pertanyaan "bagaimana keadaan kita sekarang atau seberapa baik langkah yang telah dilakukan" (Cutlip, Center \& Broom, 2011).

Berdasarkan penjelasan di atas, komunikasi jelas berperan penting bagi perkembangan organisasi. Bertahan atau tidaknya sebuah organisasi, salah satunya ditentukan oleh faktor bagaimana cara menyampaikan pesan kepada publik. Melalui pesan-pesan tersebut, berbagai informasi penting mengenai perusahaan bisa tersalurkan, termasuk upaya-upaya persuasif untuk membangun dan mempertahankan citra organisasi. Dalam hal ini, PR dapat berperan aktif karena memiliki kewenangan untuk menjaga hubungan dengan berbagai pihak untuk menciptakan harmoni.

Selain itu, PR juga perlu melibatkan diri dalam perumusan rencana strategis, memahami posisi perusahaan, memahami konflik yang ada di antara pihak-pihak dalam perusahaan, mengetahui rencana yang dimiliki oleh setiap bagian dalam organisasi, dan ikut membentuk arah perusahaan dengan memberikan pandangan mengenai masa depan dan opini dari publik masyarakat (Kasali, 1995).

Selain kegiatan yang bersifat strategis, PR juga berhubungan langsung dengan kegiatan kampanye, terutama untuk meyakinkan dan membangkitkan kesadaran atau tanggung jawab sosial masyarakat mengenai aktivitas yang sedang atau akan dilakukan. Salah satu tujuan utamanya adalah untuk menciptakan dan menjaga iklim yang menguntungkan bagi pengumpulan dana. Terlebih, sifat yang melekat pada organisasi nirlaba adalah mandiri dan sukarela.

Di sisi lain, organisasi nirlaba juga perlu mengelola identitas organisasi yang meliputi visi, misi, dan budaya organisasi. Identitas organisasi tersebut sedikit banyak akan memengaruhi cara berkomunikasi, budaya pegawai, dan produk yang sedang atau akan dikelola organisasi. Semua ini akan menghasilkan reputasi di mata publik organisasi nirlaba.

Reputasi sendiri merupakan gabungan dari perilaku, komunikasi, dan kinerja (Doorley \& Garcia, 2007). Reputasi berbeda dengan citra meskipun saling terkait. Citra adalah kesan awal yang terbentuk, pengetahuan, dan persepsi sesaat, sementara reputasi adalah 
kesimpulan dan penilaian akhir publik setelah berinteraksi dalam jangka waktu yang panjang. Jadi, reputasi merupakan penilaian jangka panjang yang dapat membuat seseorang menyimpulkan apakah sebuah organisasi dinilai baik atau buruk, hebat atau biasa, besar atau kecil, kuat atau lemah, sangat dihargai atau sebaliknya (Alifahmi, 2008). Buah reputasi adalah nama baik dan akarnya kepercayaan. Tanpa kepercayaan, tidak akan ada penghormatan. Jika sudah dipercaya maka nama baik pun dapat dengan mudah dimiliki.

Sebagai salah satu unsur terpenting dalam dunia bisnis, reputasi perusahaan merupakan indikator penting bagi keberhasilan perusahaan tersebut. Dalam konteks ini, menjaga reputasi perusahaan merupakan tanggung jawab bersama setiap departemen yang ada dalam perusahaan. Namun demikian, Public Relations menjadi garda terdepan dalam menjaga dan meningkatkan reputasi perusahaan di mata publik.

Sementara itu, aspek menentukan yang tak kalah pentingnya dalam aktivitas Public Relations adalah evaluasi, di mana keberlangsungan atau perubahan sebuah program yang dijalankan organisasi nirlaba dapat diukur. Dengan kata lain, kegiatan evaluasi terhadap program dapat menentukan apakah program tersebut layak dipertahankan atau diubah. Artinya, evaluasi terhadap sebuah program dapat menjadi dasar bagi perencanaan program selanjutnya.

Dalam kaitannya dengan penjelasan di atas, penelitian ini bertujuan untuk mengetahui (1) metode identifikasi masalah Public Relations pada LAZ Dompet Dhuafa; (2) proses perencanaan dan pemrograman LAZ Dompet Dhuafa; (3) strategi aksi dan komunikasi LAZ Dompet Dhuafa; dan (4) proses evaluasi program LAZ Dompet Dhuafa.

\section{KERANGKA TEORI}

\section{Komunikasi Perusahaan}

Istilah komunikasi perusahaan (corporate communication) terdengar lebih popular di kalangan praktisi dan akademisi Inggris. Dalam bukunya Corporate Communication for Manager, Peter Jakson (1987) mendefinisikan corporate communication sebagai keseluruhan kegiatan komunikasi perusahaan yang dilakukan untuk mencapai tujuan-tujuan yang sudah direncanakan. Tujuan-tujuan yang telah direncanakan tersebut adalah berbagai kegiatan yang diorganisasikan dalam serangkaian kampanye atau program terpadu serta berlangsung secara berkesinambungan dan teratur. Jadi, corporate communication sama sekali bukan kegiatan yang bersifat sembarangan atau dadakan.

Sebagai penerapan strategi komunikasi yang terkait dengan strategi perusahaan, corporate communication sangat menentukan "keunggulan bersaing organisasi bisnis" di zaman globalisasi Argenti (1998). Pernyataan tersebut dilandasi oleh empat hal berikut ini. 
1. Teknologi komunikasi menjadi semakin canggih sehingga informasi dapat berpindah dengan sangat cepat karena adanya internet.

2. Masyarakat lebih terdidik sehingga mereka lebih skeptis dan tidak mudah percaya terhadap tujuan-tujuan perusahaan yang terdapat dalam moto dan taglinenya.

3. Terdapat standar yang sangat tinggi agar pesan yang disampaikan perusahaan dapat diterima dalam benak publik.

4. Kondisi perusahaan menjadi semakin kompleks dan perusahaan mau tak mau harus berkomunikasi dengan publik.

Sebagai fungsi, komunikasi korporasi terpusat dan menyebar secara menyeluruh di dalam organisasi. Sementara sebagai proses, proses-proses digunakan oleh organisasi untuk menyampaikan berbagai pesan kepada kelompok konstituen kunci. Proses-proses tersebut merupakan gabungan antara pertemuan, wawancara, pidato, laporan, iklan citra, dan komunikasi online (Hardjana, 2008).

Corporate communication sangat diperlukan untuk menjembatani perusahaan sebagai pelaku bisnis dengan para stakeholders. Corporate communication merupakan fungsi dalam manajemen yang merupakan kekuatan dalam mendukung sukses perusahaan dalam jangka panjang di tengah persaingan yang semakin kompetitif.

Secara teknis, corporate communication digunakan untuk menunjukkan asumsi bahwa organisasi dilihat sebagai sosok yang mempunyai kepribadian dan identitas dan harus membangun hubungan dengan lingkungan sekitarnya. Asumsi ini terkait dengan konsep strategic management yang menangani kelangsungan hidup dan masa depan organisasi (Hardjana, 2008). Dalam pendekaatan strategis, fungsi komunikasi korporasi meliputi berbagai aspek, mulai dari komunikasi citra dan identitas, iklan dan advokasi, komunikasi pemasaran, komunikasi keuangan, relasi media, urusan politik dan pemerintah, komunikasi karyawan, sampai kepada kegiatan komunikasi krisis.

Sementara itu, fungsi dan tujuan corporate communication adalah sebagai penghubung antara perusahaan dengan stakeholders (publik yang berkepentingan), sebagai kegiatan komunikasi dalam menciptakan dan memelihara image perusahaan, memantau, mengkaji dan tanggap terhadap sikap atau persepsi khalayak, dan menjalin hubungan baik dengan lembaga-lembaga yang terkait.

Fungsi corporate communication juga tidak semata-mata bertujuan membangun image positif di mata publiknya, tetapi juga untuk mendukung kegiatan-kegiatan marketing dalam mencari keuntungan dan dapat dipercaya oleh publiknya. Menurut Argenti (1998), komunikasi 
korporasi idealnya menjadi sikap terhadap komunikasi atau seperangkat kebiasaan mental yang dihayati oleh segenap pegawai. Pada akhirnya, wujud komunikasi organisasi dapat dilihat pada produk komunikasi yang dihasilkan, antara lain memo, surat, laporan, website, email, pidato, atau berita selebaran.

\section{Komunikasi Organisasi}

Secara fungsional, komunikasi organisasi dapat diartikan sebagai pertunjukan dan penafsiran pesan di antara unit-unit komunikasi yang merupakan bagian dari organisasi tertentu (Pace \& Faules, 2010). Artinya, komunikasi yang berlangsung dalam organisasi merupakan proses menciptakan dan saling menukar pesan dalam hubungan yang saling bergantung satu sama lain untuk mengatasi lingkungan yang selalu berubah-ubah.

Salah satu tantangan besar dalam komunikasi organisasi adalah bagaimana menyampaikan informasi ke seluruh bagian organisasi dan bagaimana menerima informasi dari seluruh bagian organisasi. Proses ini berhubungan dengan aliran informasi. Pada hakikatnya, informasi bersifat tidak bergerak, dan yang sesungguhnya terlihat adalah penyampaian pesan, interpretasi terhadap penyampaian tersebut, dan penciptaan penyampaian lainnya. Penciptaan, penyampaian, dan interpretasi pesan merupakan proses yang mendistribusikan pesan-pesan ke seluruh organisasi (Pace \& Faules, 2010).

Aliran komunikasi yang dibangun dalam internal perusahaan akan menghasilkan budaya komunikasi organisasi. Budaya organisasi merupakan salah satu bentuk identitas organisasi yang harus dikelola dengan baik karena akan berpengaruh terhadap reputasi organisasi; reputasi organisasi terbangun dari perpaduan antara identitas organisasi dan citra organisasi. Dari identitas organisasional akan berlanjut memengaruhi cara berkomunikasi, budaya pegawai/anggota organisasi, dan produk/jasa yang dikelola organisasi sehingga menghasilkan corporate identity (identitas perusahaan/lembaga). Semua ini akan menghasilkan reputasi di mata seluruh publik organisasi.

Dalam konteks organisasi nirlaba, pembentukan identitas organisasi dapat dimulai dengan mengelola budaya organisasi, visi, dan misi perusahaan. Di sisi lain, pantauan media terhadap organisasi membantu publik semakin memahami perusahaan/lembaga, demikian pula pembicaraan orang (word of mouth) yang baik mengenai lembaga akan membantu terbentuknya reputasi lembaga di mata publik organisasi eksternal.

\section{Public Relations}

Public Relations adalah fungsi manajemen yang membangun dan mempertahankan hubungan baik dan bermanfaat antara organisasi dengan publik yang memengaruhi 
kesuksesan atau kegagalan organisasi tersebut (Cutlip, Center \& Broom, 2011). Definisi tersebut menempatkan Public Relations sebagai bagian dari fungsi manajemen. Definisi ini juga mengidentifikasi pembentukan dan pemeliharaan hubungan baik yang saling menguntungkan antara organisasi dengan publik sebagai basis moral dan etis dari profesi Public Relations. Pada saat yang sama, definisi ini mengemukakan kriteria untuk menentukan apa itu Public Relations dan apa yang bukan Public Relations.

Menurut Ruslan (2005), istilah Public Relations dapat diartikan sebagai fungsi manajemen yang menilai sikap publik, mengidentifikasi kebijaksanaan, dan tata cara seseorang atau orang demi kepentingan publik serta merencanakan dan melakukan suatu program kegiatan untuk meraih pengertian, pemahaman, dan dukungan serta penilaian yang baik dari publiknya.

Dalam manajemen organisasi, Public Relations perlu melakukan serangkaian proses agar memperoleh sumber-sumber data yang mendukung sehingga program yang dijalankan bisa tepat sasaran. Sebagaimana dikatakan Sam Black (dalam Rusdianto, 2013), Public Relations is about reputation, perception, credibility, confidence, harmony, and seeking mutual understanding, based on truth and full informations."

Titik perhatian Public Relations juga tertuju pada perkembangan dan perubahan lingkungan organisasi. Perubahan lingkungan organisasi bisa terjadi karena berbagai hal, dan bisa menjadi penyebab jatuhnya nama baik dan reputasi organisasi. Berbagai isu dan masalah yang mendera perusahaan akan memengaruhi reputasi perusahaan. Isu-isu tersebut bisa mengenai lingkungan hidup, Hak Asasi Manusia (HAM), hak-hak perempuan, hak-hak anak, demokrasi, dan lain sebagainya.

Posisi Public Relations dalam organisasi menjadi sangat penting dalam mengantarkan reputasi organisasi. Namun demikian, upaya mewujudkan reputasi bukan hanya menjadi tanggung jawab Public Relations saja, tetapi juga menjadi tanggung jawab seluruh bagian dalam organisasi. Public Relations menjadi sarana menyampaikan informasi kepada publik sehingga mereka tahu apa yang terjadi dalam perusahaan. Keintegrasian seluruh bagian dalam organisasi akan mempermudah dan memuluskan jalannya reputasi. Keintegrasian ini terjadi pada bagian marketing communications, management communications, dan organization communications. Ketiga komponen tersebut harus terintegrasi ketika mengkomunikasikan segala sesuatu mengenai merek produk atau merek perusahaan dengan satu suara secara simultan dan berkelanjutan.

Keintegrasian ini akan menghasilkan kekompakan dan keserasian informasi sehingga reputasi perusahaan lebih cepat dan mudah diraih. Keintegrasian ini juga akan memicu keterikatan dan persamaan suara bagi public intern perusahaan. 


\section{Manajemen Public Relations}

Kata manajemen berasal dari kata manage (bahasa Latinnya manus) yang berarti memimpin, menangani, mengatur, atau membimbing. George R. Terry mendefinisikan manajemen sebagai sebuah proses yang khas dan terdiri dari tindakan-tindakan, seperti perencanaan, pengorganisasian, pengaktifan, dan pengawasan yang dilakukan untuk menentukan serta mencapai sasaran-sasaran yang telah ditetapkan melalui pemanfaatan sumberdaya manusia dan sumber-sumber lainnya. Dari definisi tersebut dapat dijabarkan empat fungsi spesifik yang dimiliki seorang manajer, yaitu planning (perencanaan), organizing (pengorganisasian), leading (kepemimpinan), dan controlling (pengendalian).

Sebagai alat manajemen modern, Public Relations merupakan alat manajemen modern yang secara struktural merupakan bagian integral dari suatu kelembagaan atau organisasi. Artinya, fungsi Public Relations tidak terpisah dari fungsi kelembagaan atau dengan kata lain melekat pada manajemen perusahaan. Hal tersebut menjadikan Public Relations dapat menyelenggarakan komunikasi dua arah (secara timbal balik) antara organisasi yang diwakilinya dengan publiknya. Peranan ini turut menentukan sukses tidaknya visi, misi, dan tujuan bersama organisasi.

Dalam bentuknya yang paling maju, Public Relations adalah bagian dari proses perubahan dan pemecahan masalah dalam organisasi yang dilakukan secara ilmiah. Cutlip, Center dan Broom (2011) mengidentifikasi empat langkah proses manajemen Public Relations sebagai praktisi perubahan dan pemecah masalah.

Pertama, mendefinisikan masalah, di mana hal tersebut meliputi deskripsi latar belakang masalah, identifikasi kebutuhan publik, melakukan penyelidikan dan memonitor opini. Menurut Cutlip, Center dan Broom, analisis situasi harus dilakukan berdasarkan metodologi riset ilmiah dan pendekatan formal, bukan sekedar intuitif. Analisis situasi membutuhkan investigasi supaya mampu menghasilkan buku fakta dalam bentuk informasi yang melibatkan pemangku kepentingan internal dan eksternal. Untuk konteks internal biasanya menghasilkan audit komunikasi, namun konteks eksternal mempunyai dimensi positif dan negatif di mata publiknya.

Kedua, membuat perencanaan dan program. Dalam membuat perencanaan, Public Relations sebaiknya menjadi bagian dari harapan manajemen dan mampu berpikir strategis. Konsep berpikir ini fokus pada penentuan tujuan dasar jangka panjang, mengadopsi tindakan, dan alokasi sumberdaya yang tepat untuk melaksanakan tujuan.

Ketiga, aksi dan komunikasi, yaitu mengimplementasikan program tindakan dan komunikasi yang didesain untuk mencapai tujuan spesifik. Kesesuaian, prioritas, dan pengukuran hasil yang tepat dalam setiap aktivitas merupakan titik poin utama yang akan 
menentukan keberhasilan pada tahap implementasi. Beberapa hal yang ada dalam konsep aksi dan komunikasi adalah: (1) tindakan nyata, yaitu mengambil langkah strategis dan taktis berdasarkan analisis SWOT, di mana salah satu pertimbangannya adalah target jangka waktu; (2) komunikasi, di mana prinsip utamanya adalah terjadi kesamaan makna dan mampu meminimalisir bias; (3) identifikasi faktor yang menjadi halangan atau dukungan, yang dalam terminologi ini berkaitan dengan hal apa yang menjadi halangan dan pendukung dalam implementasi manajemen komunikasi nirlaba, di mana faktor-faktor tersebut akan dijadikan sebagai patok duga (benchmarking) dalam penanganan komunikasi program pelayanan di masa mendatang.

Keempat, evaluasi. Semua bentuk aktivitas kehumasan baik kuantitatif maupun kualitatif harus bisa diukur untuk menentukan tingkat efektivitas perencanaan, implementasi, dan dampaknya terhadap publik. Menurut Glen Broom dan David Dozier, setiap evaluasi yang dilakukan terhadap suatu program dimaksudkan untuk mengetahui dampak yang dihasilkan.

\section{Organisasi Nirlaba}

Organisasi nirlaba adalah organisasi yang dalam menjalankan aktivitasnya tidak berorientasi menghasilkan keuntungan bisnis (not for profit organization). Ukuran keberhasilan yang hendak dicapai organisasi nirlaba bukan keuntungan secara materi. Akan tetapi, hal itu bukan berarti organisasi nirlaba tidak boleh menghasilkan keuntungan. Hanya saja, keuntungan yang diperoleh dari aktivitas organisasi semata-mata ditujukan hanya untuk menutupi biaya yang timbul dari kegiatan operasional atau keuntungan yang diperoleh akan disalurkan kembali bagi kegiatan utama organisasi. (Widodo \& Kustiawan, 2001).

Karena Sifat organisasi nirlaba berbeda dengan organisasi bisnis pada umumnya, organisasi nirlaba memiliki karakterististik sebagaimana berikut ini (Widodo \& Kustiawan, 2001).

1. Sumberdaya organisasi berasal dari para penyumbang yang tidak mengharapkan pembayaran kembali atau manfaat ekonomi yang sebanding dengan jumlah sumberdaya yang diberikan.

2. Menghasilkan barang atau jasa atau tanpa tujuan memupuk laba. Jika organisasi menghasilkan laba maka jumlahnya tidak pernah dibagikan kepada para pendiri/pemilik organisasi tersebut.

3. Tidak ada kepemilikan seperti lazimnya organisasi bisnis. Artinya, kepemilikan dalam organisasi nirlaba tidak dapat dijual, dialihkan, atau ditebus kembali, atau kepemilikan 
tersebut tidak mencerminkan proporsi pembagian sumberdaya organisasi pada saat likuidasi/pembubaran organisasi.

Organisasi nirlaba dibentuk untuk mengusung berbagai jenis program aktivitas oleh pengelolanya. Ada yang berbentuk lembaga keagamaan. organisasi kesejahteraan sosial, hingga lembaga swadaya masyarakat. Menurut Henry Hansman (dalam Nainggolan, 2005) organisasi nirlaba terbagi menjadi beberapa jenis.

1. Lembaga nirlaba donasi. Lembaga nirlaba yang termasuk ke dalam kategori donasi adalah lembaga yang mengandalkan pendapatannya dari sumbangan.

2. Lembaga nirlaba komersial. Lembaga nirlaba yang termasuk dalam kategoeri komersial adalah lembaga yang pendapatannya berasal dari anggotanya berupa charge dari pemakaian hartanya.

3. Lembaga nirlaba mutual yaitu lembaga yang dikelola oleh para anggotanya yang notabene adalah pemakai jasa dari lembaga.

4. Lembaga nirlaba entrepreneurial, yaitu lembaga yang dikelola oleh para profesional yang memang khusus diberi gaji untuk mengelolanya.

\section{Reputasi Perusahaan}

Reputasi merupakan pendekatan komunikasi yang dilandasi oleh pemikiran tentang kegalauan lingkungan dan ketidakpastian masa depan, karena reputasi adalah hasil tindakan penyehatan hidup agar terhindar dari krisis. Dengan demikian, konsep reputasi sebenarnya merupakan antitesis dari krisis (Hardjana, 2008).

Perusahaan sangat berkepentingan memiliki reputasi yang baik dari stakeholder. Reputasi akan menciptakan kepercayaan, dan dengan kepercayaan ini perusahaan akan memperoleh dukungan dan kesetiaan dari para stakeholder, seperti sebuah siklus yang pada akhirnya akan memberikan manfaat kepada perusahaan.

John Dalton dan Susan Croft (2003) dalam Managing Corporate Reputation menjelaskan bahwa reputasi adalah the sum values that stakeholders attribute to a company, based on their perception and interpretation of the image that the company communicates over time. Dari pengertian tersebut, reputasi harus diperjuangkan atau harus diusahakan. Bahkan, perusahaan atau organisasi harus memiliki langkah dan perencanaan yang tepat dan berjalan terus menerus dengan menjadi pendengar apa yang dikatakan para stakeholder perusahaan.

Sebuah survei yang dimuat dalam Corporate Reputation Watch 2002 menyebutkan tiga penyebab ancaman dalam reputasi. Pertama, kritik terhadap perusahaan atau produk yang 
disampaikan melalui media cetak atau media penyiaran. Kedua, bencana yang mengganggu produksi. Ketiga, tuduhan dari kelompok-kelompok kepentingan atau pelanggan tentang keamanan produk. Namun demikian, penghambat utama reputasi adalah perilaku perusahaan, khususnya perilaku yang berhubungan dengan harapan-harapan publik kepada perusahaan.

Menurut Hardjana (2008), ada enam kunci dalam memupuk reputasi. Pertama, efektivitas bersaing, yang meliputi kaliber manajemen, strategi pengembangan melalui research and development, dan kesehatan keuangan. Kedua, kepemimpinan pasar, mencakup kepemimpinan industri, diferensiasi produk yang tegas dan dekat dengan pasar. Ketiga, orientasi pada pelanggan, yang mencakup kualitas unggul atau nilai yang sepadan harga, punya komitmen pada pelanggan, citra yang jernih dan jelas. Keempat, keakraban/kesayangan atau tidak asing bagi pelanggan. Kelima, budaya organisasi, meliputi standar etika yang tinggi, tanggung jawab sosial, dan karyawan yang berkualitas. Keenam, komunikasi, termasuk iklan yang efektif dan sponsor kegiatan-kegiatan penting.

Sementara menurut Chandra (2010), Public Relations bertujuan membangun reputasi perusahaan melalui mekanisme 3P: pencitraan, publikasi di media massa dan pendapat umum.Sesuatu yang terbangun di media massa merupakan "realitas" yang akan bekerja membangun pendapat umum publik. Pencitraan yang dilakukan Public Relations tidak secara langsung dan bukan bertransaksi jual-beli dengan media massa. Publikasi di sini berarti menjadi berita. Artinya, pihak ketiga (media massa) bercerita mengenai pihak kesatu (perusahaan) kepada pihak kedua (publik). Proses komunikasi menggunakan media massa dalam konteks media relations membawa Public Relations kepada konsep feedback dan feed-forward. Kritik dianggap sebagai feedback organisasi yang menjadi salah satu komponen penting, sementara perusahaan perlu bersikap proaktif dengan memberikan feed-forward kepada publiknya melalui kegiatan komunikasi.

Faktor penting untuk mendongkrak reputasi adalah kemampuan berkomunikasi, inovasi, dan sumberdaya manusia. Jika dicermati, naik turunnya reputasi perusahaan lebih disebabkan karena kritik dari media dan kemampuan berkomunikasi. Karena itu, keberadaan Public Relations ditujukan untuk membangun, mengembangkan, dan meningkatkan reputasi dalam pandangan stakeholder melalui komunikasi.

\section{Peran Public Relations dalam Organisasi Nirlaba}

Karena organisasi nirlaba bersifat mandiri dan sukarela maka Public Relations dalam hal ini harus menggalakkan kampanye untuk meyakinkan dan membangkitkan kesadaran/ tanggung jawab sosial masyarakat tentang nilai aktivitasnya. Kampanye juga digalakkan 
dalam mengembangkan saluran komunikasi dengan publik sehingga dapat menciptakan dan memelihara iklim yang menguntungkan bagi pengumpulan dana.

Dalam kebanyakan agen nirlaba, Public Relations bertujuan untuk (1) mendefinisikan atau memberi brand organisasi, mendapat penerimaan misinya, dan melindungi reputasi perusahaan; (2) mengembangkan saluran komunikasi dengan pihak-pihak yang dilayani organisasi; (3) menciptakan dan memelihara iklim yang baik untuk mengumpulkan dana; (4) mendukung pengembangan dan pemeliharaan kebijakan publik yang cocok untuk misi organisasi; (5) memberi informasi dan motivasi konstituen organisasional utama (seperti karyawan, sukarelawan, dan komisaris) untuk mengabdikan diri mereka dan bekerja secara produktif dalam mendukung misi, tujuan, dan sasaran organisasi (Cutlip, Center \& Broom, 2011).

Public Relations dalam organisasi nirlaba dituntut untuk mampu membuat program Public Relations, misalnya tulisan (Public Relations writing), buku mini, brosur, naskah pidato (radio/televisi), atau film dengan menggunakan beragam media komunikasi, misalnya publisitas pers, iklan, pidato umum, peragaan, pameran, majalah, artikel majalah, kisah, berita. Hal ini ditujukan untuk memberi informasi dan memotivasi konstituen utama organisasi (karyawan, sukarelawan) untuk mengabdikan diri mereka dan berkarya secara produktif untuk mendukung misi, tujuan, dan sasaran organisasi.

Sama dengan Public Relations pada organisasi lainnya, fungsi Public Relations dalam organisasi nirlaba menentukan sikap peduli terhadap organisasi (pencitraan), menilai kesan publik terhadap organisasi, mencari apakah publik mengetahui tujuan, pelayanan, dan pelaksanaan organisasi, menentukan kesalahpahaman yang terjadi, melaksanakan penelitian opini yang sangat penting untuk menyusun kebijakan, perencanaan, dan penilaian efektivitas program Public Relations.

\section{METODE PENELITIAN}

Objek penelitian ini adalah evaluasi manajemen Public Relations Lembaga Amil Zakat (LAZ) Dompet Dhuafa. Meskipun objek penelitian hanya dibatasi pada evaluasi manajemen Public Relations LAZ Dompet Dhuafa, namun aspek-aspek fact finding, perencanaan dan pemrograman, aksi dan komunikasi LAZ Dompet Dhuafa tetap menjadi perhatian dalam penelitian ini. Penelitian ini menggunakan metode kualitatif dengan pendekatan studi kasus eksploratif jenis single case holistic. Metode manajemen Public Relations yang digunakan mengacu pada model empat langkah proses manajemen menurut Cutlip, Center dan Broom (2011). Data primer dalam penelitian ini diperoleh melalui wawancara mendalam, sementara data sekunder bersumber dari studi pustaka dan dokumentasi. 


\section{HASIL DAN PEMBAHASAN}

Lembaga Amil Zakat (LAZ) Dompet Dhuafa memiliki dua divisi yang berbeda tugas dan fungsinya, yaitu Divisi Penghimpunan dan Divisi Pendayagunaan. Divisi Penghimpunan berfungsi menghimpun potensi-potensi zakat dan sedekah umat untuk disalurkan melalui program-program LAZ Dompet Dhuafa dan untuk keberlangsungan organisasi, sementara Divisi Pendayagunaan berfungsi membuat inovasi program penyaluran dan pendayagunaan dana umat.

Posisi Public Relations pada LAZ Dompet Dhuafa terintegrasi terhadap seluruh bagian dalam organisasi baik Divisi Penghimpunan maupun Divisi Pendayagunaan. Pada Divisi Pendayagunaan, keintegrasian Public Relations terdapat pada manajer program dan kordinator masing-masing program. Integrasi ini menghasilkan keserasian dan kekompakan informasi yang keluar dari dalam organisasi sehingga reputasi organisasi lebih cepat dan mudah diraih.

Model komunikasi public relations LAZ Dompet Dhuafa adalah model asimetris dua arah, yaitu model komunikasi antara organisasi dengan publiknya yang bersifat dua arah dengan mencoba menangkap umpan balik dari public (Kholisoh \& Yenita, 2015; Sumarto, 2016). Posisi publik organisasi akan ditanggapi dan ditindaklanjuti untuk memenuhi prinsip organisasi, yaitu melayani kebutuhan publik. Sementara itu, penyampaian pesan menggunakan prinsip persuasi dalam upaya memperoleh dukungan publik (Anggraeni, Siswoyo \& Nurfalah, 2014; Rahutomo , 2013; Syamsurizal, 2016).

Dalam proses manajemen Public Relations pada LAZ Dompet Dhuafa, proses pertama yang dilakukan adalah mendefinisikan masalah (atau peluang). Proses pertama ini mencakup penyelidikan dan pemantauan pengetahuan, opini, sikap, dan perilaku pihak-pihak yang terkait dengan dan dipengaruhi oleh tindakan dan kebijakan organisasi. Hanya saja, LAZ Dompet Dhuafa tidak melakukan riset khusus terkait dengan perencanaan program; riset dilakukan hanya melalui penemuan fakta-fakta baru di lapangan berdasarkan program-program yang dijalankan sebelumnya. Penemuan fakta di lapangan ini pun tidak untuk membuat dan mengembangkan program-program baru, melainkan hanya untuk menyesuaikan penempatan para penerima manfaat program yang sudah ada agar sesuai dengan kebutuhan mereka. Ketika penelitian ini dilakukan, Grand Program LAZ Dompet Dhuafa adalah Lamusta (Layanan Mustahik). Awalnya, para penerima manfaat ditempatkan dalam program Lamusta. Tetapi, setelah profil dan kebutuhannya diidentifikasi, penerima manfaat akan ditempatkan pada program yang sesuai dengan kebutuhannya. 
Dalam sebuah perencanaan, proses riset khusus seharusnya menjadi hal yang penting untuk dilakukan (Brunner, 2010; Sulistyaningtyas, 2010; Naeami, et al., 2016). Dalam konteks LAZ Dompet Dhuafa, proses riset tersebut antara lain melakukan kontak personal yang mendalam kepada para penerima manfaat, mencari informan kunci, membuat kelompok fokus atau forum komunitas, dan membuat saluran telepon bebas.

Namun demikian, LAZ Dompet Dhuafa memiliki satu jejaring khusus yang berfungsi melakukan riset terhadap keseluruhan programnya, yaitu Indonesia Magnificence of Zakat (IMZ). Salah satu aktivitas utama IMZ adalah melakukan riset melalui program Indonesia Zakat and Development Report (IZDR). Alat ukur yang digunakan IMZ ketika melakukan riset adalah Headcount Ratio (H), Poverty Gap Index (P1), Income Gap(I), Sen Index (P2) dan FGT Index (P3). Untuk Headcount Ratio diketahui, terjadi penurunan dari 0,96 menjadi 0,75 setelah program (21,6\%), sementara Income Gap Ratio dari 0,46 menjadi 0,36 (22,2\%) setelah intervensi program. Hasil yang ditemukan dalam riset biasanya mengenai penurunan angka kemiskinan, tingkat kedalaman kemiskinan, dan tingkat keparahan kemiskinan.

Langkah kedua manajemen Public Relations adalah perencanaan dan pemrograman. Rencana Public Relations diawali dengan pernyataan misi organisasi yang selanjutnya dikaitkan dengan temuan fakta (Cutlip, Center \& Broom, 2011).

Dalam misi organisasi LAZ Dompet Dhuafa, tertuang salah satu misi organisasi, yaitu mengembangkan zakat sebagai alternatif dalam pengentasan kemiskinan (Darna \& Fatimah, 2016; Beik, 2009; Dulkiah, 2016; Firmansyah, 2013; Hidayat, 2017; Qomari, 2017). Misi tersebut selaras dengan tujuan utama yang ingin dicapai dari program-program tematik dan nontematik, yaitu mendistribusikan zakat dengan tepat sasaran dan tepat guna. Artinya, program yang dirancang disesuaikan dengan kebutuhan primer para penerima manfaat.

Adapun perencanaan LAZ Dompet Dhuafa tertuang dalam Rencana Strategis (Renstra) dan KPI (Key Performance Indicator), sedangkan rencana anggaran tersusun dalam RKAT (Rencana Kegiatan dan Anggaran Tahunan). Dalam Renstra tersusun tujuan setiap program, publik sasaran (penerima manfaat), dan sasaran yang harus dicapai setiap publik untuk mencapai tujuan program. Menurut Cutlip, Center \& Broom (2011), dalam perencanaan dan pemrograman terdapat tiga unsur penting: tujuan program (apa solusi yang diharapkan), publik sasaran (siapa yang harus direpson, dijangkau, dan dipengaruhi oleh program), dan sasaran (apa yang harus dicapai oleh setiap publik untuk mencapai tujuan program). .

Sementara itu, anggaran kegiatan tahunan LAZ Dompet Dhuafa ditetapkan oleh Dewan Syariah Dompet Dhuafa Pusat sebesar 15\% dari total pendapatan zakat dan sedekah per tahun. Angka tersebut (15\%) dialokasikan untuk seluruh program pemberdayaan dan management office (termasuk gaji karyawan, operasional, dan perawatan gedung). 
Adapun implementasi program dilakukan oleh masing-masing tim program, di mana setiap tim dibawahi oleh seorang koordinator program yang bertanggung jawab terhadap pelaksanaan dan keberhasilan program. Program tematik yang memiliki beberapa program dikepalai seorang kordinator program, sementara program nontematik yang juga memiliki beberapa program dikepalai oleh beberapa koordinator, dan masing-masing kordinator bertanggung jawab terhadap satu program nontematik.

Langkah ketiga proses manajemen Public Relations adalah aksi dan komunikasi. Strategi komunikasi mendukung program aksi. Pertama, memberi informasi kepada publik internal dan eksternal tentang tindakan. Kedua, membujuk publik untuk mendukung dan menerima tindakan. Ketiga, memberi petunjuk kepada publik bagaimana cara menerjemahkan niat ke dalam aksi (Cutlip, Center \& Broom, 2011).

Strategi komunikasi LAZ Dompet Dhuafa kepada publik internal dilakukan melalui pertemuan-pertemuan yang diadakan setiap minggu, bulan, dan tahun. Khusus dalam pertemuan tahunan dibahas penyusunan Renstra dan RKAT. Adapun strategi komunikasi kepada pihak eksternal adalah berupa pemberian pesan utama yang ingin disampaikan dalam program-program LAZ Dompet Dhuafa, antara lain membantu kaum dhuafa dengan mengajak partisipasi masyarakat, baik masyarakat yang berada di sekitar program maupun masyarakat umum yang dikategorikan sebagai muzakki (donatur). Dalam mengkomunikasikan setiap program kepada publik eksternalnya, LAZ Dompet Dhuafa juga melakukan optimalisasi website dan media sosial (Basit, 2018; Pienrasmi, 2015; Reitz, 2012; Wang, 2015; Zulfikar, 2017).

Langkah terakhir proses manajemen Public Relations adalah proses evaluasi. Evaluasi adalah proses yang perlu dilakukan terus menerus dan memiliki peran penting. Dalam salah satu elemen riset evaluasi (Cutlip, Center \& Broom, 2011), disebutkan bahwa untuk meningkatkan dan mendukung proses riset evaluasi, seorang praktisi Public Relations harus mempertahankan dan melibatkan partisipasi secara intens dan langsung serta berkomunikasi dengan pengguna potensial dan stakeholder lainnya selama melakukan riset.

LAZ Dompet Dhuafa tidak melakukan riset evaluasi secara khusus, terlebih yang berkaitan dengan dampak program secara langsung. Riset dilakukan secara bertahap mulai dari bulanan, caturwulan, semesteran, dan tahunan. Riset evaluasi tersebut hanya melibatkan publik internal organisasi, tidak melibatkan publik eksternal baik pengguna potensial (donatur) ataupun penerima manfaat.

Adapun mekanisme evaluasinya adalah dengan melihat sejauh mana target program yang sudah tercapai; jika belum tercapai, langkah yang dilakukan adalah merumuskan ulang 
strategi yang diperlukan. Perumusan ulang tersebut berupa perluasan wilayah dan kuantitas penerima manfaat jika target penerima manfaat di bawah standar target pencapaian yang telah ditetapkan dalam RKAT tahunan.

\section{KESIMPULAN}

Fungsi Public Relations pada LAZ Dompet Dhuafa dilakukan oleh Manajer Program dan Koordinator masing-masing program, terutama dalam kaitannya dengan divisi pendayagunaan. Adapun fungsi Public Relations secara menyeluruh dilakukan oleh jejaring LAZ Dompet Dhuafa, yaitu Indonesian Magnificence of Zakat (IMZ), baik yang berhubungan dengan riset, proses komunikasi maupun evaluasi.

Dalam menganalisis situasi, LAZ Dompet Dhuafa tidak melakukan riset khusus terkait perencanaan program; riset yang dilakukan LAZ Dompet Dhuafa hanya melalui fakta-fakta baru di lapangan melalui program-program yang sudah ada sebelumnya. Fakta-fakta yang ditemukan berupa kebutuhan-kebutuhan mustahik (penerima manfaat) yang lebih spesifik. Dari fakta-fakta yang ditemukan, divisi program mengidentifikasi dan menempatkan penerima manfaat kepada program yang cocok dengan kebutuhan mereka.

Perencanaan program tematik dan nontematik LAZ Dompet Dhuafa dilakukan melalui rapat kerja tahunan dengan mengevaluasi program yang sudah ada sebelumnya, untuk kemudian menganalisis fakta-fakta di lapangan terkait masalah yang timbul atau kebutuhan mustahik yang ada. Dari dasar itulah perencanaan program dibuat. Sementara anggaran program yang ditetapkan Dewan Syariah adalah sebesar $15 \%$ dari total pendapatan LAZ Dompet Dhuafa selama satu tahun dan tertuang dalam RKAT tahunan.

Pesan utama yang ingin disampaikan dalam program-program LAZ Dompet Dhuafa antara lain membantu kaum dhuafa dengan mengajak partisipasi masyarakat, baik masyarakat yang berada di sekitar program maupun masyarakat umum yang dikategorikan sebagai muzakki (donatur). Dalam mengkomunikasikan pesan tersebut kepada pihak eksternal, LAZ Dompet Dhuafa memaksimalkan website resminya dan media sosial.

Evalusi program LAZ Dompet Dhuafa tidak melibatkan publik eksternal. Evaluasi dilakukan secara bertahap, mulai dari bulanan, caturwulan, semester, dan tahunan. Adapun mekanisme evaluasinya adalah dengan melihat sejauh mana target program sudah tercapai; jika belum tercapai akan dilakukan perumusan ulang strategi, yaitu dengan menempatkan mustahik (penerima manfaat) pada program-program LAZ Dompet Dhuafa berdasarkan kebutuhan mustahik. Perumusan ulang strategi juga mencakup perluasan wilayah dan kuantitas penerima manfaat jika target penerima manfaat di masih bawah target pencapaian yang telah ditetapkan dalam RKAT. 
Reputasi yang dimiliki oleh LAZ Dompet Dhuafa adalah dampak dari opini publik yang sudah terbentuk dan mengkristal (crystalizing of public opinion). Opini publik yang telah terbentuk mengenai LAZ Dompet Dhuafa memengaruhi seluruh jejaring LAZ Dompet Dhuafa, termasuk jejaring Lembaga Amil Zakat (LAZ).

\section{REFERENSI}

Al Neaimi, Mouza (et al.). (2016). "Research in Public Relations". Higher Education of Social Science, 10(1): 1-10.

Alifahmi, Hifni. (2008). Marketing Communications Orchestra. Bandung: Examedia Publishing.

Anggraeni, Novi, Mukarto Siswoyo, dan Farida Nurfalah. (2014). "Strategi Public Relations dalam Mendukung Pembangkit Listrik Nasional (PLN)". Jurnal ASPIKOM, 2(3): 206-220.

Argenti, Paul A. (1998). Corporate Communication. Boston: McGraw Hill.

Basit, Abdul dan Tri Herni Rahmawati. (2017). “Cyber Public Relations (E-PR) dalam Brand Image Wardah Kosmetik dengan Pedekatan Mixed Method". Nyimak Journal of Communication, 1(2): 197-208.

Beik, Irfan Syauqi. (2009). "Analisis Peran Zakat dalam Mengurangi Kemiskinan: Studi Kasus Dompet Dhuafa Republika". Jurnal Pemikiran dan Gagasan, Volume 2, 1-11.

Brunner, Brigitta R. (2010). "The Importance of Research to Public Relations". Review of Communication, 3(4): 419-423.

Cutlip, Scott. M., Allen H. Center dan Glen M. Broom. (2011). Effective Public Relations. New Jersey: Prentice Hall Inc.

Dalton, John and Susan Croft. (2003). Managing Corporate Reputation: The New Currency. Thorogood

Darna dan Fatimah. (2016). Peran Organisasi Pengelola Zakat Nasional dalam Memutus Rantai Kemiskinan di Indonesia. National Conference of Applied Sciences Engineering, Business and Information Technology.

Doorley, John and Helio Fred Garcia. (2007). Reputation Management: The Key to Successful Public Relations and Corporate Communication. Taylor \& Francis.

Dulkiah, Moh. (2016). “Peranan Lembaga Amil Zakat (LAZ) dalam Pemberdayaan Masyarakat Miskin melalui Pengembangan usaha Mikro di Wilayah Jawa Barat”. JISPO, 6(2): 30-49.

Firmansyah. (2013). "Zakat sebagai Instrumen Pengentasan Kemiskinan dan Kesenjangan Pendapatan". Jurnal Ekonomi dan Pembangunan, 21(2): 170-190.

Hardjana, Andre A. (2008). "Komunikasi dalam Manajemen Reputasi Korporasi”. Jurnal ILMU KOMUNIKASI, 5(1): 1-24. 
Hertanto, Widodo dan Kustiawan Teten. (2001). Akuntansi dan Manajemen Keuangan untuk Organisasi Pengelola Zakat. Jakarta: Institut Manajemen Zakat.

Hidajat, Rachmat. (2017). "Penerapan Manajemen Zakat Produktif dalam Meningkatkan Ekonomi Umat di PKPU (Pos Keadilan Peduli Umat) Kota Makassar". Millah: Jurnal Studi Agama, 17(1): 63-84.

Jackson, Peter C. (1987). Corporate Communications for Managers. Trans-Atlantic Publications.

Kasali, Rhenald. (1995). Manajemen Public Relations: Konsep dan Aplikasinya di Indonesia. Jakarta: Pustaka Utama Grafiti.

Kholisoh, Nur dan Yenita. (2015). "Strategi Komunikasi Public Relations dan Citra Positif Organisasi (Kasus Public Relations Rumah Sakit "X" di Jakarta)". Jurnal IImu Komunikasi, 13(3): 195-209.

Nainggolan, Pahala. (2005). Akuntansi Keuangan Yayasan dan Lembaga Nirlaba Sejenis. Jakarta: PT. Raja Grafindo Persada.

Nurdin, Ali. (2013). "Transformasi Dompet Dhuafa dari Lembaga Amil Zakat menjadi Lembaga Sosial-Kemanusiaan". Al-Turas, 19(2): 345-368.

Pace, R. Wayne dan Don F. Faules. (2010). Komunikasi Organisasi: Strategi Meningkatkan Kinerja Perusahaan. Bandung: PT. Remaja Rosdakarya.

Pienrasmi, Hanindyalaila. (2015). "Pemanfaatan Social Media oleh Praktisi Public Relations di Yogyakarta”. Jurnal Komunikasi, 9(2): 199-210.

Qomari, Nur. (2017). "Zakat: Solusi Pengentasan Kemiskinan". Iqtishodia Jurnal Ekonomi Syariah, 2(2): 15-25.

Rahutomo, Adi Nugroho. (2013). "Strategi Humas dalam Mempublikasikan Informasi Pelayanan Publik pada PT. PLN Persero Rayon di Samarinda Hilir". eJournal IImu Komunikasi, 1(2) 324-340.

Reitz, Amy. (2012). "Social Media's Function in Organizations: A Functional Analysis Approach". Global Media Journal, 5(2): 41-56.

Rusdianto, Ujang. (2013). CSR Communication a Framework for PR Practitionsers. Yogyakarta: Graha Ilmu.

Ruslan, Rosady. (2005). Manajemen Humas dan Manajemen Komunikasi: Konsep dan Aplikasinya. Jakarta: PT. Raja Grafindo Persada.

Ruslan, Rosady. (2007). Manajemen Public Relations dan Media Komunikasi: Konsepsi dan Aplikasi. Jakarta: PT. Raja Grafindo Persada.

Sulistyaningtyas, Ike Devi. (2010). "Riset sebagai Ujung Tombak Keberhasilan Program Public Relations". Jurnal ILMU KOMUNIKASI, 7(2): 171-186. 
Sumarto, Rumsari Hadi. (2016). “Komunikasi dalam Kegiatan Public Relations". INFORMASI Kajian IImu Komunikasi, 46(1): 63-72.

Syamsurizal. (2016). "Strategi Komunikasi Persuasif dalam Aktivitas Pemasaran (Studi Deskriptif Komunikasi Persuasif Presenter (Staff Pemasaran) dalam Merekrut Calon Mahasiwa baru di Politeknik LP3I Jakarta)". Jurnal Lentera Bisnis, 5(2): 126-138.

Wang, Yuan. (2015). "Incorporating Social Media in Public Relations: A Synthesis of Social Media-Related Public Relations Research". Public Relations Journal, 9(3): 1-14.

Zulfikar, Alif Ryan. (2017). "Pengaruh Social Media Marketing terhadap Brand Awareness Trust pada Followers Instagram Dompet Dhuafa Cabang Yogyakarta". Al-Idrah: Jurnal Manajemen dan Administrasi Islam, 1(2): 279-294. 
